\title{
The Problems of Performance Assessment of Japanese Language Subjects Based on E-Learning Using E-lingo Platform
}

\author{
Lenny Puspitasari ${ }^{1, *}$ Miftachul Amri ${ }^{1}$ Syamsul Sodiq ${ }^{2}$ \\ ${ }^{1,2}$ Education of Language and Literature, Universitas Negeri Surabaya, Indonesia \\ *Corresponding author: Email: lenny.20053@mhs.unesa.ac.id
}

\begin{abstract}
Distance Learning (DL) implementation began to be mandatory throughout Indonesia as part of efforts to suppress the spread of COVID-19. The implementation with E-learning model is applied in the teaching and learning process from kindergarten to higher education which demands innovative and accessible learning, not limited by distance and minimal obstacles. In this case, the assessment on cognitive, affective, and psychomotor aspects is considered to be lacking in terms of validity and reliability and an observational assessment cannot be carried out. This study aims to reveal the disadvantages of assessment on psychomotor aspects through E-lingo platform. The task is in the form of videos that are assessed with an analytic rubric. This study employed a qualitative descriptive study with semistructured interviews on several teachers who teach productive and non-productive subjects. The use of E-lingo platform indicated having some disadvantages, especially its limitations in the number of uploads and the uploaded file types. The advantages of E-lingo platform are that the platform can cover the entire data of students and teachers with details of online time and tasks whether daily tasks, mid-term test, and final test. This platform activity can also be monitored by the school including students and teachers directly.
\end{abstract}

Keywords: E-learning, E-lingo, Performance assessment, Analytic rubric.

\section{INTRODUCTION}

The COVID-19 pandemic which began to spread in early 2019 has disrupted the entire life and system of various countries in the economic, social and cultural fields, including education. Since 2020, the Indonesian government has implemented the Learning From Home (LFH) model in the hope of reducing the spread of COVID-19 from school clusters. This Learning From Home (LFH) model is still being applied today. This learning model or better known as online learning model has caused a lot of polemics in society. From the beginning, the implementation of the online learning model had several conditions that must be met as a basic requirement for the implementation of learning with minimal obstacles, namely the availability of learning facilities and infrastructure, such as gadgets and internet connections. This online learning is a new matter that requires great effort from stakeholders as policy makers, school principals as people in charge, teachers, and students. As an archipelagic country, regional conditions in Indonesia also greatly influence the extent to which government policies can succeed in implementing this online learning model.

The impact of this massive change in teaching methods has an impact on students' understanding of material mastery and practice. As the safest solution during the pandemic, the online concept is considered not optimal in terms of monitoring the process, validity, and reliability of students' tasks since it is considered unobservable which is one of the requirements in learning assessments. In this study, the researchers intend to show the obstacles in the assessment process of students' tasks with E-learning model through the Elingo platform used by students and teachers of SMK Walisongo 2 Gempol. The results of this current study are expected to be able to map the difficulties and disadvantages, both in the task model which may be inappropriate or in the platform itself which may not be able to cover the needs of the task. Lastly, this is expected to bring about an improvement in the quality of the tasks so that it has a positive impact on teachers and students, namely obtaining maximum results in 
terms of validity and reliability from tasks on the Elingo platform.

\section{METHODS}

This research is a qualitative descriptive study which means that the data collected is used and analysed in written form. The semi-structured interview method is employed for vocational high school teachers who teach productive and non-productive subjects. The results of the interview indicate the advantages and disadvantages of using E-lingo platform as well as obstacles in assessing students' performance using E-learning model. The results of this study can then be used to overcome motor difficulties and obstacles felt by teachers in assessing students' psychomotor aspects by using performance assessments through analytic rubrics [9]. There are four assessment criteria that are considered quite valid since they cover the objectives of the psychomotor assessment, namely (1) clarity of voice, (2) intonation or pronunciation, (3) attitude/ojigi, and (4) content.

\section{RESULTS AND DISCUSSION}

\subsection{E-Learning}

According to Regulation of the Minister of Education and Culture No.109/2013, E-learning or also called Distance Learning (DL) is a teaching and learning process that is carried out remotely through the use of various communication media, such as computers, smartphones, or other gadgets that are connected to the internet, and can communicate in two directions from teachers and students [5]. Clearly, it is also explained that E-learning is individual or group learning that uses internet networks to provide flexibility for students in learning (with whom, anytime and anywhere). This learning model can also be combined with the face-to-face model. This combination is called the blended learning model. In Indonesia, the implementation of E-learning has begun to be implemented in 2012 which is stated in regulation No. 12/2012 on Higher Education [5]. This regulation regulates the use of the Distance Learning (DL) in which the E-learning model is included. This E-learning model is in accordance with the nation's development goals, namely improving the quality and relevance of higher education, increasing access to the quality of higher education, increasing the Gross Participation Rate (GPR) for higher education, equitable distribution of affordable and flexible higher education across space and time.

During the pandemic, the implementation of Elearning is chosen as the most possible step in order to reduce the spread of COVID-19. However, this implementation still has pros and cons to its advantages and disadvantages. There are several advantages of using this E-learning model. First, it is easily accessible only with the internet and a laptop or smartphone. Second, the cost is more affordable since learning can be done anywhere without worrying about distance, only with the internet. This is cheaper than the cost of taking a face-to-face course. Third, learning time becomes more flexible since tasks can be done anywhere and anytime as long as they are within the time limit. Fourth, it can improve the insight since the learning model is more diverse and innovative with the existence of E-learning [7].

Apart from the advantages, there are also disadvantages of E-learning model, namely the limitations of the internet. In Indonesia, internet access cannot be available anywhere at the required speed so that it requires the right place to study and a good internet connection to be able to access learning platforms. Besides, the reduced interaction with teachers is also a disadvantage of E-learning model. In this case, teachers and students cannot meet face-to-face so that it can cause inconvenience to some students. As a result, students' understanding of the material may not be as good as when learning face-to-face. Another disadvantage is the lack of supervision in learning. Through the internet network, supervision on tasks is not as good as the face-to-face model so that it is prone to fraud. According to the interview results, cognitive assignments cannot be measured properly since they are prone to fraud by copying and pasting the work of other friends. Meanwhile, psychomotor measurement is not so well developed and motivated since students only imitate examples without providing innovation.

\subsection{Performance Assessment}

According to Hart [6], assessment is the process of gathering information about students, namely what they know and what they can do. Besides, assessment is a form of teacher's and student's interaction in integrated activities in the teaching and learning process, both face-to-face and online learning [7]. Through the assessment, information to provide significant feedback will be obtained so as to improve the quality of students' learning and the quality of learning practices. This is in accordance with Mertler [4] who stated that the purpose of assessment is to diagnose students' difficulties, place students according to their abilities, provide needed feedback, and evaluate learning.

In general, there are three areas of learning that are measured, namely learning attitudes (affective), learning knowledge (cognitive), and learning skills (psychomotor). In this case, performance assessment is one of the assessment techniques used to determine the mastery level of students' skills through appearance tests, demonstrations, or real work practices [1]. This assessment requires students to present a certain competency using practical tests, projects, and portfolio 
assessments both individually and in groups. According to Mertler [4], the assessment instrument used can be in the form of a checklist or a rating scale equipped with a rubric or assessment criteria.

A similar study was also conducted by Sundari [7] in the research "Model of Performance Assessment of Science Subjects Based on Character Values at Junior High Schools in Ternate, North Maluku". This study referred to the implementation of the School-Based Curriculum (SBC) which has a performance assessment in its authentic assessment. It is intended to produce a product in the form of a performance assessment instrument based on character values, especially in science subjects at junior high schools in Ternate city. In this study, the results obtained that the characterbased character assessment is known to be valid with a value of $85.7 \%$. From these results, it can be concluded that the product of developing a character-based performance assessment model is feasible to use and the revised results of this assessment rubric can be used as an alternative for teachers to be developed, such as the assessment of the observation procedure in the implementation of the procedure [1].

\subsection{Validity and Reliability}

According to Azwar [2], validity means the extent to which the accuracy of a measuring instrument (test) in carrying out its measuring function. A test is said to have high validity if the tool performs the measuring function correctly or provides the appropriate measurement results. This means that the measurement results can reflect the actual facts of what is being measured. A test with a particular purpose may not be suitable for a test with another purpose. Therefore, a test must be adapted to the purpose of the test. The validity of the task that measures students' performance with Elearning model through E-lingo platform can be seen from the students' video assessment rubric. This assessment rubric consists of four important points, namely (1) clarity of voice (are students able to pronounce in a clear voice and can the articulation be heard?), (2) intonation or pronunciation (are students able to pronounce well according to the Japanese pronunciation as shown in the example?), (3) attitude/ojigi (are students able to show attitudes and use ojigi appropriately?), and (4) content (is the selfintroduction text made by students developed or is it just the original text as exemplified?).

Reliability means the extent to which the measurement results can be trusted. A measurement result can be trusted if the measurement results for the same group of subjects are obtained relatively the same measurement results in several times [3]. This applies as long as the aspects measured from within the subject have not changed. It is supported by Matondang [3] study stated that a test is reliable if it always gives the same results in the same group at different times, and reliability is one of the characteristics of a good measurement instrument character.

\subsection{E-lingo}

In the early days of the COVID-19 pandemic, Elingo was the first platform used by SMK Walisongo 2 Gempol to seek safe education in accordance with government instructions, namely implementing of technology-based distance learning. E-lingo platform does not only contain students' tasks and learning, but also contains complete data about teachers, teaching hours, mid-term test questions and so on. In this case, each teacher and student has an account to be able to access this platform with the user ID and password provided by the school. On this platform, each teacher can observe students' log-in activities and see students' liveliness. Likewise for the evaluation process of the school, the appointed school admin also has access to be able to monitor the activity of teachers in giving tasks to students.

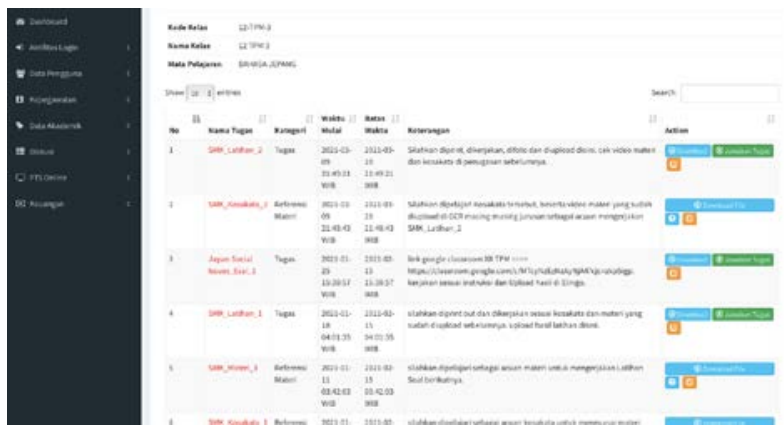

Figure 1 E-lingo Platform (Materials and Tasks)

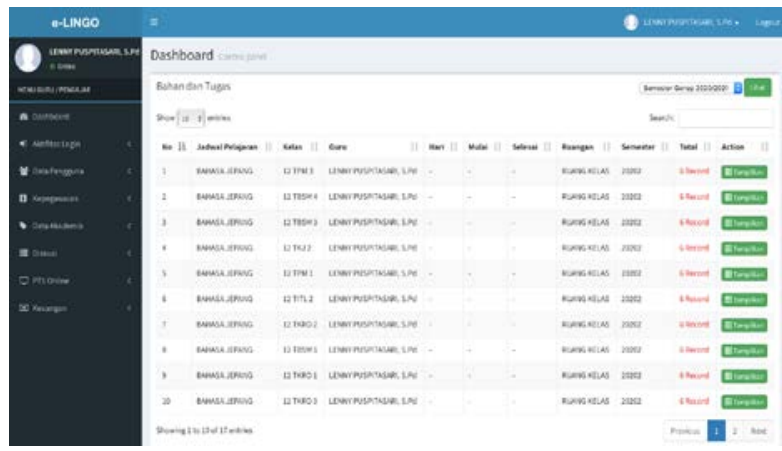

Figure 2 E-lingo Platform (Materials and Tasks for each class)

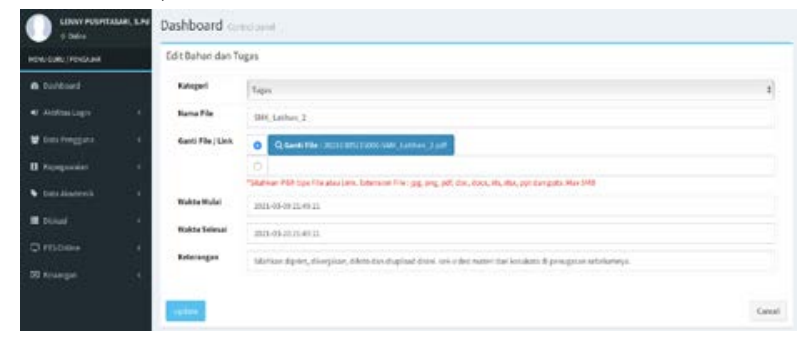

Figure 3 E-lingo Platform (Task page) 
In the Academic Data section with sub Students' Data and Task Materials, teachers can upload the task file along with the deadline to complete the task and instructions that must be filled in the description section. Uploaded file types can be selected Jpg, Png, Pdf, Doc, Docx, Xls, Xlsx, PPT, and PPTx with a maximum of $5 \mathrm{Mb}$.

The performance assessment used in this study is an individual task model in the form of a simple selfintroduction practice task in Japanese language. Students are given an example of a simple text along with a video uploaded in Google Classroom. Then, they are instructed to make a simple introductory text by being allowed to add content to the self-introduction by taking references from YouTube or other sources. The scoring criteria and scoring method are made to facilitate scoring with some final results in the form of a total score. In this task, the teacher uses the analytic rubric scoring model since it is considered more detailed in terms of assessment through several aspects. Students will be assessed from several criteria based on the assessment rubric as Table 1:

Table 1. Individual Assessment Rubric

\begin{tabular}{|c|c|c|c|}
\hline No. & Rated Aspect & $\begin{array}{c}\text { Qualitative } \\
\text { Value }\end{array}$ & $\begin{array}{c}\text { Quantitative } \\
\text { Value }\end{array}$ \\
\hline 1. & Clarity of Voice & & \\
\hline 2. & $\begin{array}{l}\text { Intonation or } \\
\text { Pronunciation }\end{array}$ & & \\
\hline 3. & Attitude (Ojigi) & & \\
\hline 4. & Content & & \\
\hline & Total Score & & \\
\hline
\end{tabular}

\subsection{Task}

In the self-introduction chapter, the task that should be in the form of a face-to-face class appearance is changed to a task to make a simple video uploaded on the E-lingo platform and assisted by Google Classroom. The results of the students' task scoring can be inputted directly on the E-lingo platf1orm so that students can see the results of their respective work. The assessment criteria are shown in the Table 2 as below: a rating scale (80-100) for the qualitative value "satisfactory" with a quantitative value of 4, (70-79) for a qualitative value of "good" with a quantitative value of 3, (60-69) for the qualitative value of "enough" with a quantitative value of 2, (45-69) for the qualitative value of "less enough" with a quantitative value of 1 .
Table 2. Assessment criteria

\begin{tabular}{|c|c|c|}
\hline Indicator Criteria & $\begin{array}{c}\text { Qualitative } \\
\text { Value }\end{array}$ & $\begin{array}{c}\text { Quantitative } \\
\text { Value }\end{array}$ \\
\hline $80-100$ & Satisfactory & 4 \\
\hline $70-79$ & Good & 3 \\
\hline $60-69$ & Enough & 2 \\
\hline $45-59$ & Less enough & 1 \\
\hline
\end{tabular}

Advantages and Disadvantages of the E-lingo Platform

Advantages:

(1) It is a platform developed and used by the school itself so that it can be developed as needed.

(2) A platform that contains a detailed database related to teachers' data, students' data, and attendance that are directly connected to the school system.

(3) Both students and teachers automatically have accounts on this platform without first registering.

(4) Teachers have access to be able to view students' last log-in and monitor students' liveliness.

(5) A platform that makes it easier for teachers to conduct test assessments and task assessments since they are all on the same platform along with data for each student in one class and major.

Disadvantages:

(1) This platform does not have a video upload feature due to the limited capacity of the E-lingo platform so that other platforms, such as Google Classroom must be used as a complement.

(2) This platform does not support the synchronous learning model since it can only be used for the asynchronous learning model in the form of students' tasks.

(3) This platform can only upload one data file in each task so that it must upload more than once if teachers want to provide material with different file formats.

(4) This platform is prone to fraud by copying and pasting other students' tasks.

\section{CONCLUSION}

As one of the E-learning models, the Distance Learning (DL) model is a learning model that is considered relevant to the current pandemic conditions. In accordance with direct instructions from the government to be able to carry out the Distance Learning (DL) process safely, intelligently, and accessible from anywhere, using the E-lingo platform is one solution that is easy to operate. This platform has 
advantages and disadvantages in terms of operation when compared to other applications. Therefore, teachers collaborate by adding the use of the Google Classroom application to optimize the teaching and learning process and also maximize students' understanding. In terms of the results of the assessment, E-learning is considered lack in validity and reliability to measure students' abilities when using the performance assessment model. This is because one of the conditions is observable. In this pandemic period, it is not possible to observe directly, especially the attitudes and performance skills of students. As a result, they are prone to fraud by copying and pasting the work of other friends for cognitive aspect assessment. From the psychomotor aspect, students are less motivated to produce original and innovative performances.

\section{REFERENCES}

[1] J. Juhairiyah, “Asesmen Konten Isi Bidang Studi,” Jurnal Pedagogik, vol. 4, no. 1, pp. 62-80, 2017.

Available: https://ejournal.unuja.ac.id/index.php/pedagogik/ar ticle/view/8

[2] S. Azwar, Sikap Manusia Teori dan Pengukurannya. Yogyakarta: Liberty, 1988.

[3] Z. Matondang, "Validitas dan Reliabilitas suatu Penelitian,” Jurnal Tabularasa, vol. 6, no. 1, pp. 87-97, 2009. Available: http://digilib.unimed.ac.id/705/

[4] C.A. Mertler, Classroom Assessment: A Practical Guide for Educator. New York: Routledge, 2017.

[5] Ristekdikti, "Kebijakan Pendidikan Jarak Jauh dan E-Learning di Indonesia," Kementrian Riset, Teknologi, dan Pendidikan Tinggi, 2016. [Online] Available: $\quad$ http://kopertis3.or.id/v2/wpcontent/uploads/Paulina-Pannen-Kebijakan-PJJdan-E-Learning.pdf. [Accessed June 12, 2021]

[6] D. Hart, Authentic Assessment. A Hand Book for Education. Menlo Park, CA: Addison-Wesley Publishing Company, 1994.

[7] S. Sundari, "Model Pengembangan Asesmen Kinerja Mata Pelajaran IPA Berbasis Karakter Di SMP Kota Ternate Maluku Utara,” Jurnal EduBio Tropika, vol. 2, no. 1, pp. 121-186, 2014 http://jurnal.unsyiah.ac.id/JET/article/view/5 $\underline{242}$

[8] Wantiknas, "Empat kelebihan dan kekurangan dalam menerapkan E-learning," Wantiknas.go.id, 2020.

[Online]

Available: http://www.wantiknas.go.id/id/berita/e mpat-kelebihan-dan-kekurangan-dalammenerapkan-e-learning. [Accessed June 12, 2021]
[9] P. Dawson, “Assessment rubrics: Towards clearer and more replicable design, research, and practice," Assessment \& Evaluation in Higher Education, pp. 1-15, 2017. 